\title{
Effect of citrus-based products on urine profile: A systematic
}

\section{review and meta-analysis [version 1; peer review: 2 approved]}

\author{
Fakhri Rahman (D1) Ponco Birowo (D1) Indah S. Widyahening2,3, Nur Rasyid (D)1 \\ ${ }^{1}$ Department of Urology, Dr. Cipto Mangunkusumo National General Hospital, Faculty of Medicine, Universitas Indonesia, Jakarta \\ Pusat, 10430, Indonesia \\ ${ }^{2}$ Department of Community Medicine, Faculty of Medicine, Universitas Indonesia, Jakarta Pusat, 10310, Indonesia \\ ${ }^{3}$ Centre for Clinical Epidemiology \& Evidence-based Medicine, Dr. Cipto Mangunkusumo National General Hospital - Faculty of \\ Medicine, Universitas Indonesia, Jakarta Pusat, 10430, Indonesia
}

V1 First published: 06 Mar 2017, 6:220

https://doi.org/10.12688/f1000research.10976.1

Latest published: 06 Mar 2017, 6:220

https://doi.org/10.12688/f1000research.10976.1

\begin{abstract}
Background. Urolithiasis is a disease with high recurrence rate, 30$50 \%$ within 5 years. The aim of the present study was to learn the effects of citrus-based products on the urine profile in healthy persons and people with urolithiasis compared to control diet and potassium citrate. Methods. A systematic review was performed, which included interventional, prospective observational and retrospective studies, comparing citrus-based therapy with standard diet therapy, mineral water, or potassium citrate. A literature search was conducted using PUBMED, COCHRANE, and Google Scholar with "citrus or lemonade or orange or grapefruit or lime or juice" and "urolithiasis" as search terms. For statistical analysis, a fixed-effects model was conducted when $p>0.05$, and random-effects model was conducted when $p<$ 0.05. Results. In total, 135 citations were found through database searching with 10 studies found to be consistent with our selection criteria. However, only 8 studies were included in quantitative analysis, due to data availability. The present study showed a higher increased in urine $\mathrm{pH}$ for citrus-based products (mean difference, $0.16 ; 95 \%$ CI 0.01-0.32) and urinary citrate (mean difference, 124.49; $95 \%$ CI 80.24-168.74) compared with a control group. However, no differences were found in urine volume, urinary calcium, urinary oxalate, and urinary uric acid. From subgroup analysis, we found that citrus-based products consistently increased urinary citrate level higher than controls in both healthy and urolithiasis populations. Furthermore, there was lower urinary calcium level among people with urolithiasis. Conclusions. Citrus-based products could increase urinary citrate level significantly higher than control. These results should encourage further research to explore citrus-based products as a urolithiasis treatment.
\end{abstract}

Keywords

Citrus, citrate, potassium citrate, urolithiasis, urine profile

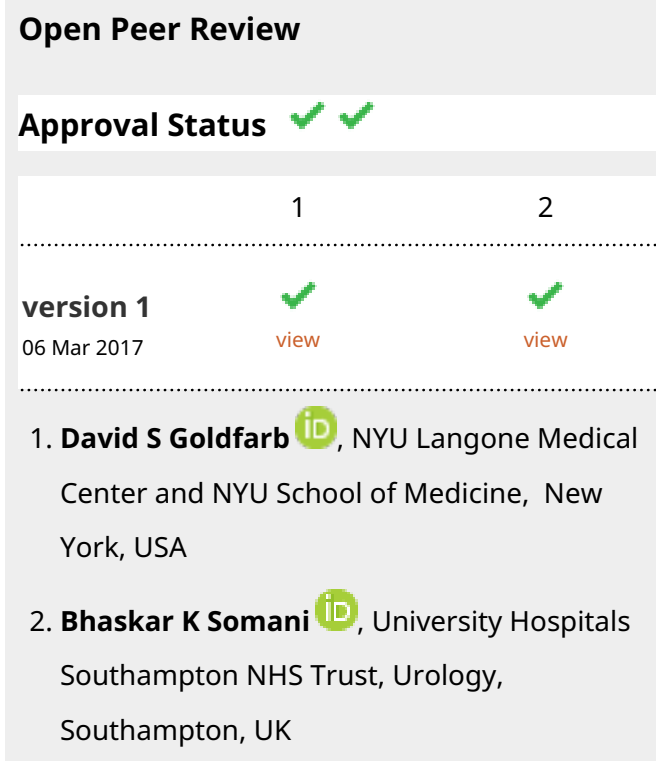

Any reports and responses or comments on the article can be found at the end of the article. 
Corresponding author: Nur Rasyid (nur.rasyid@gmail.com)

Competing interests: No competing interests were disclosed.

Grant information: This study received grants from Directorate of Research and Community Service (DRPM), Universitas Indonesia in 2013 (2739/H.R12/HKT.05.00/2013).

The funders had no role in study design, data collection and analysis, decision to publish, or preparation of the manuscript.

Copyright: $\odot 2017$ Rahman F et al. This is an open access article distributed under the terms of the Creative Commons Attribution License, which permits unrestricted use, distribution, and reproduction in any medium, provided the original work is properly cited. Data associated with the article are available under the terms of the Creative Commons Zero "No rights reserved" data waiver (CC0 1.0 Public domain dedication).

How to cite this article: Rahman F, Birowo P, Widyahening IS and Rasyid N. Effect of citrus-based products on urine profile: A systematic review and meta-analysis [version 1; peer review: 2 approved] F1000Research 2017, 6:220

https://doi.org/10.12688/f1000research.10976.1

First published: 06 Mar 2017, 6:220 https://doi.org/10.12688/f1000research.10976.1 


\section{Introduction}

Humans have suffered urinary tract stones for centuries ${ }^{1}$. The incidence and prevalence of urolithiasis are different between geographic locations, depending on age and sex distribution, stone composition and stone location ${ }^{2}$. Risk of stone development has been shown to be $5-10 \%$ with a higher prevalence in men than women ${ }^{3}$. Urolithiasis is a common disease with significant morbidity and cost worldwide ${ }^{4-6}$. Based on National Health and Nutrition Examination survey, kidney stones affect 1 in 11 people in the United States, and an epidemiological increase was found in 2012 compared to 19947 . Additional data from Dr. Cipto Mangunkusumo National General Hospital, Indonesia's national referral hospital, showed an increase in stone disease prevalence from 182 patients in 1997 to 847 patients in $2002^{8}$. Moreover, it is further worsen by its high recurrence rate reaching $30-50 \%$ within 5 years ${ }^{7}$.

Calcium-based urinary tract stone is the most common stone composition found in urolithiasis ${ }^{9,10}$. Supersaturation is believed to be the mechanism behind calcium stone formation ${ }^{11}$. One factor in determining urine stone formation or stone recurrence is urine profile, which is defined as urine volume and its composition. Hypercalciuria and hypocitraturia are the most common urine abnormalities found among calcium stone-formers ${ }^{12}$. A high fluid intake could prevent stone formation by lowering supersaturation, whereas citrate could prevent stone formation by ionizing urinary calcium $^{13,14}$. Food that is rich of citrate is citrus. There are wide variety of citrus fruits and derivate products that can be easily obtained, such as lemonade, grapefruit, orange, lime, and citrus-based juice. Several studies had already been conducted to learn the effect of citrus-based products on urine profile. However, the results between those studies were contradictive. Therefore, our study aimed to systematically review and quantify the available studies regarding the effects of citrus-based products on urine profile and its comparison to a control diet and potassium citrate.

\section{Methods}

\section{Eligibility criteria}

We included both healthy people and patients with urolithiasis history in our selection criteria. Study subjects must have consumed citrus fruits, such as orange, lime, grapefruit, or juices made from the fruits. Study designs could be interventional, prospective observational, or retrospective with standard diet therapy (any kind of mineral water), or potassium citrate, as a control group therapy. We included studies with urine profile as the outcome. We only included articles written in English or Indonesian, and those with full text article available. We excluded non-systematic review articles. We did not limit studies based on their year conducted.

\section{Search strategy}

A literature search was conducted using PUBMED, COCHRANE, and Google Scholar as search engines on August 2016. The terms "citrus OR lemonade OR orange OR grapefruit OR lime OR juice" AND "urolithiasis" were used as search terms. We also searched the list of references in included studies. We did not use any limitation in study searching.

\section{Study selection and data extraction}

All studies were screened for duplication using EndNote X6 software. Duplication-free articles underwent title and abstract examination using predetermined inclusion and exclusion criteria mentioned above. Selection of studies was selected by two authors independently. Discrepancies of opinion were resolved by discussion. All studies, which fulfilled the inclusion and exclusion criteria, underwent full text review. For every eligible full text, we extracted the following data, if available: subjects specific condition, citrusbased product used in the study, number of patients consuming citrus-based product, citrate content or its concentration, control intervention, number of individuals under control intervention. For the outcomes, we extracted urine profile data as follows: volume, $\mathrm{pH}$, calcium level, citrate level, oxalate level, and uric acid level. Measurement units used in this study are L/day for urine volume and $\mathrm{mg}$ /day for urinary calcium level, urinary citrate level, urinary oxalate level, and urinary uric acid level. All data in the form of numbers were extracted manually as mean and standard deviation for variable measurement.

\section{Assessment of bias and statistical methods}

This study used Cochrane Risk of Bias assessment tools ${ }^{15}$ and Newcastle-Ottawa scale ${ }^{16}$ to assess interventional and retrospective study's quality, respectively. These assessments of study quality were done by two authors independently. Quantitative synthesis of included studies was analyzed using Review Manager (RevMan) 5.0 software and mean difference was used as its effects size measurement. Heterogeneity of studies was assessed using chisquare. A fixed-effects model was conducted when $\mathrm{p}>0.05$, whereas a random-effect model is conducted when $\mathrm{p}<0.05$. We also conducted subgroup analysis to differentiate between healthy and urolithiasis populations.

Studies which could not be included in quantitative analysis were described qualitatively.

\section{Results}

We found 135 citations through database searching. Literature searching from the list of references found similar studies that were all already included in this study. Ten studies were found to be consistent with our selection criteria (Figure 1).

Two of ten studies had to be excluded from quantitative analysis because of the following reasons: (1) Penniston et al. ${ }^{17}$ only published baseline data and its maximal change following intervention; and (2) Tosukhowong et al. ${ }^{19}$ used medians as their outcome measurement, and due to its non-uniform distribution, we were unable to convert these to means. Therefore, eight studies were analyzed to find the effect of citrus-based products on urine profile compared to controls. However, not all of the eight studies were included in urine profile outcome measurement, due to data availability. Characteristics of the included studies and their risk of 


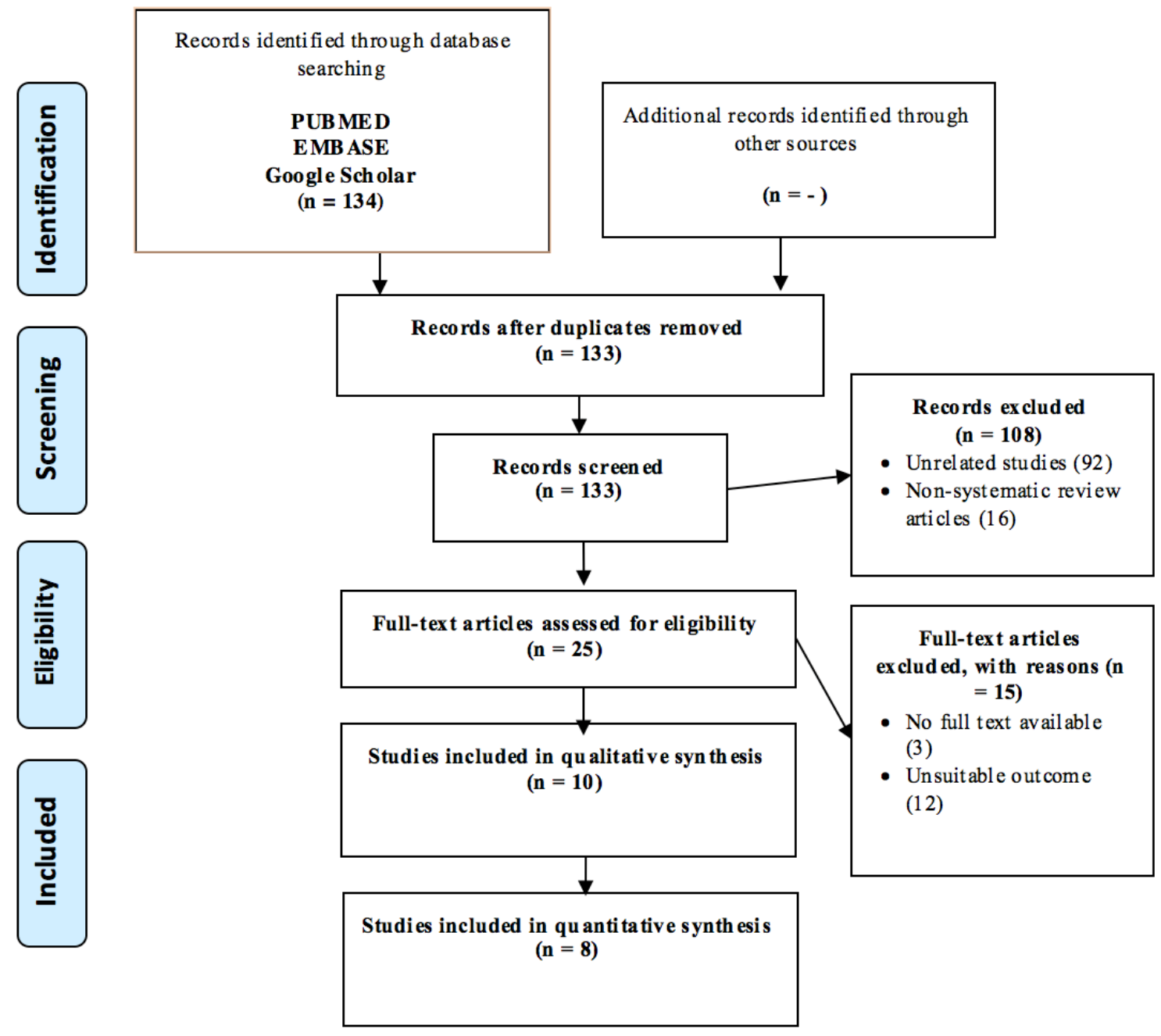

Figure 1. Study flow diagram.

bias assessment can be seen in Table 1 and Figure 2/Supplementary Table 1, respectively.

\section{Effect of citrus-based products on urine profile}

Data shows that citrus-based products increased urine $\mathrm{pH}$ (mean difference, 0.16 ; 95\% confidence interval [CI] 0.01-0.32) and urinary citrate (mean difference $124.49 ; 95 \%$ CI 80.24-168.74) to a higher extent than control treatment (Figure 3).

However, there was no statistically significant difference in urine volume (mean difference $-0.09 ; 95 \%$ CI $-0.20-0.02$ ), urinary calcium (mean difference $-5.45 ; 95 \%$ CI $-18.89-7.98$ ), urinary oxalate (mean difference $0.76 ; 95 \%$ CI $-0.47-1.98$ ) and urinary uric acid (mean difference 2.15; 95\% CI -23.96-28.27) between the two groups (Figure 4).

Subgroup analysis showed a significantly higher urinary citrate level in both the healthy population and the population with history of urolithiasis who received citrus-based therapy compared to control. However, urine $\mathrm{pH}$, which showed a statistically significant increase in urine $\mathrm{pH}$ compared to controls, did not demonstrate any differences in a subgroup analysis. On the other hand, urinary calcium was lower after consumption of citrusbased products compared to controls in the urolithiasis population. Furthermore, this study demonstrated that there was a lower urine volume in the healthy population after drinking citrus-based products compared to controls (Figure 5). We did not find any differences in other urine profile variables, either in the healthy population or the population with history of urolithiasis (Supplementary Figure 1 and Supplementary Figure 2).

We tried to conduct further analysis by excluding Aras et al. ${ }^{20}$ from quantitative analysis, due to its different study method (RCT). We still found a significant increase in urine citrate level in both mixed population (mean difference 132.46; 95\% CI 70.48-194.44) and the population with a history of urolithiasis (mean difference 159.22; 95\% CI 47.05-271.40]), as well as no statistically significant difference in urine $\mathrm{pH}$ (mean difference 0.16 ; 95\% CI -0.02-0.33). Furthermore, other variables still demonstrate similar outcomes after exclusion of Aras et al. 
Table 1. Characteristic of included studies.

\begin{tabular}{|c|c|c|c|c|c|c|}
\hline Study author and year & $\begin{array}{l}\text { Type of } \\
\text { study }\end{array}$ & Subject condition & Intervention & $\mathbf{n}$ & Control & $\mathbf{n}$ \\
\hline \multicolumn{7}{|c|}{ Study included in qualitative synthesis only } \\
\hline Penniston et al (2007) ${ }^{17}$ & RS & $\begin{array}{l}\text { Subjects with } \\
\text { calcium oxalate } \\
\text { stone }\end{array}$ & Lemonade (5.9 gr citrate) & 63 & $\begin{array}{l}\text { Lemonade ( } 5.9 \mathrm{gr} \text { citric } \\
\text { acid) plus potassium } \\
\text { citrate }\end{array}$ & 37 \\
\hline Tosukhowong et al (2008) ${ }^{19}$ & $\mathrm{RCT}$ & $\begin{array}{l}\text { Post-operative } \\
\text { subjects with } \\
\text { nephrolithiasis }\end{array}$ & $\begin{array}{l}\text { - Lime powder ( } 4.4 \text { gr citrate) } \\
\text { - Potassium citrate }\end{array}$ & $\begin{array}{l}13 \\
11\end{array}$ & Placebo & 7 \\
\hline \multicolumn{7}{|c|}{ Study included in qualitative and quantitative synthesis } \\
\hline Aras et al $(2008)^{20 *}$ & $\mathrm{RCT}$ & $\begin{array}{l}\text { Subjects with } \\
\text { hypocitraturic } \\
\text { calcium stone }\end{array}$ & $\begin{array}{l}\text { - Lemon juice (4.2 gr citrate) } \\
\text { - Potassium citrate }\end{array}$ & $\begin{array}{l}10 \\
10\end{array}$ & Water 3 L/day & 10 \\
\hline Goldfarb and Asplin (2001) ${ }^{21}$ & CBAS & Healthy subjects & Grapefruit juice & 10 & $\begin{array}{l}\text { Tap water } 240 \mathrm{ml}, 3 \text { times } \\
\text { a day }\end{array}$ & 10 \\
\hline Honow et al (2003) $)^{22}$ & CBAS & Healthy subjects & $\begin{array}{l}\text { - Orange juice } \\
\text { - Grapefruit juice } \\
\text { - Apple juice }\end{array}$ & $\begin{array}{l}3 \\
3 \\
3\end{array}$ & Mineral water & 3 \\
\hline Koff et al (2007) & CS & $\begin{array}{l}\text { Subjects with history } \\
\text { of nephrolithiasis }\end{array}$ & Lemon juice (4.5 gr citrate) & 21 & $\begin{array}{l}\text { Fluid except lemonade or } \\
\text { citrus drink }\end{array}$ & 21 \\
\hline Odvina $(2006)^{24}$ & CS & $\begin{array}{l}\text { Healthy and stone } \\
\text { former subjects }\end{array}$ & $\begin{array}{l}\text { - Orange juice (2.3 gr citrate) } \\
\text { - Lemonade (2.3 gr citrate) }\end{array}$ & $\begin{array}{l}14 \\
14\end{array}$ & Distilled water $400 \mathrm{ml}$ & 14 \\
\hline Seltzer et al (1996) ${ }^{25}$ & CBAS & $\begin{array}{l}\text { History of } \\
\text { hypocitraturic } \\
\text { calcium } \\
\text { nephrolithiasis }\end{array}$ & - Lemonade (5.9 gr citrate) & 12 & Fluid maintaining $2 \mathrm{~L}$ urine & 12 \\
\hline Sumorok et al $(2011)^{18}$ & CS & Healthy subjects & - Sunkist orange soda (3 cans) & 12 & Water 1.06 L/day & 12 \\
\hline Trinchieri et al (2002) ${ }^{26}$ & CS & Healthy subjects & - Grapefruit juice (1.4 gr citrate) & 7 & Water & 7 \\
\hline
\end{tabular}

RS - retrospective study; RCT - randomized controlled trial; CBAS - controlled before-after study; CS - crossover study. *Also included in qualitative synthesis for comparison between citrus-based product and potassium citrate.

Comparison between citrus-based products and potassium citrate in urine profile

Due to the reasons stated above, we decided to discuss the comparisons between citrus-based product and potassium citrate in a qualitative manner.

Three studies showed both citrus-based products (lemon juice and lime powder) and potassium citrate increased the level of urinary citrate significantly ${ }^{17,19,20}$. Even though no significant difference in post treatment urine profile was found between citrus-based products and potassium citrate, post-treatment citrate level in the potassium citrate group showed a 3.5 times increase from pre-treatment level, while it was only 2.5 times in the lemon juice group ${ }^{20}$. Furthermore, Penniston et al. exhibited a greater maximum increase of urinary citrate level in lemonade therapy combined with potassium citrate compared to lemonade therapy alone ${ }^{17}$.
Two studies also showed significant increase in urine $\mathrm{pH}$ in both treatment arms ${ }^{17,19}$. However, a study by Aras et al. only exhibit a significant increase in urine $\mathrm{pH}$ for the potassium citrate group ${ }^{20}$. In terms of side effects, patients in the potassium citrate group suffered gastric and oropharyngeal discomfort, although they did not require drug discontinuation ${ }^{20}$. Furthermore, potassium citrate had lower compliance compared to citrus-based therapy ${ }^{19}$.

Dataset 1. Characteristics of studies included for urine $\mathrm{pH}$

http://dx.doi.org/10.5256/f1000research.10976.d153056

Dataset 2. Characteristics of studies included for urinary citrate

http://dx.doi.org/10.5256/f1000research.10976.d153057 


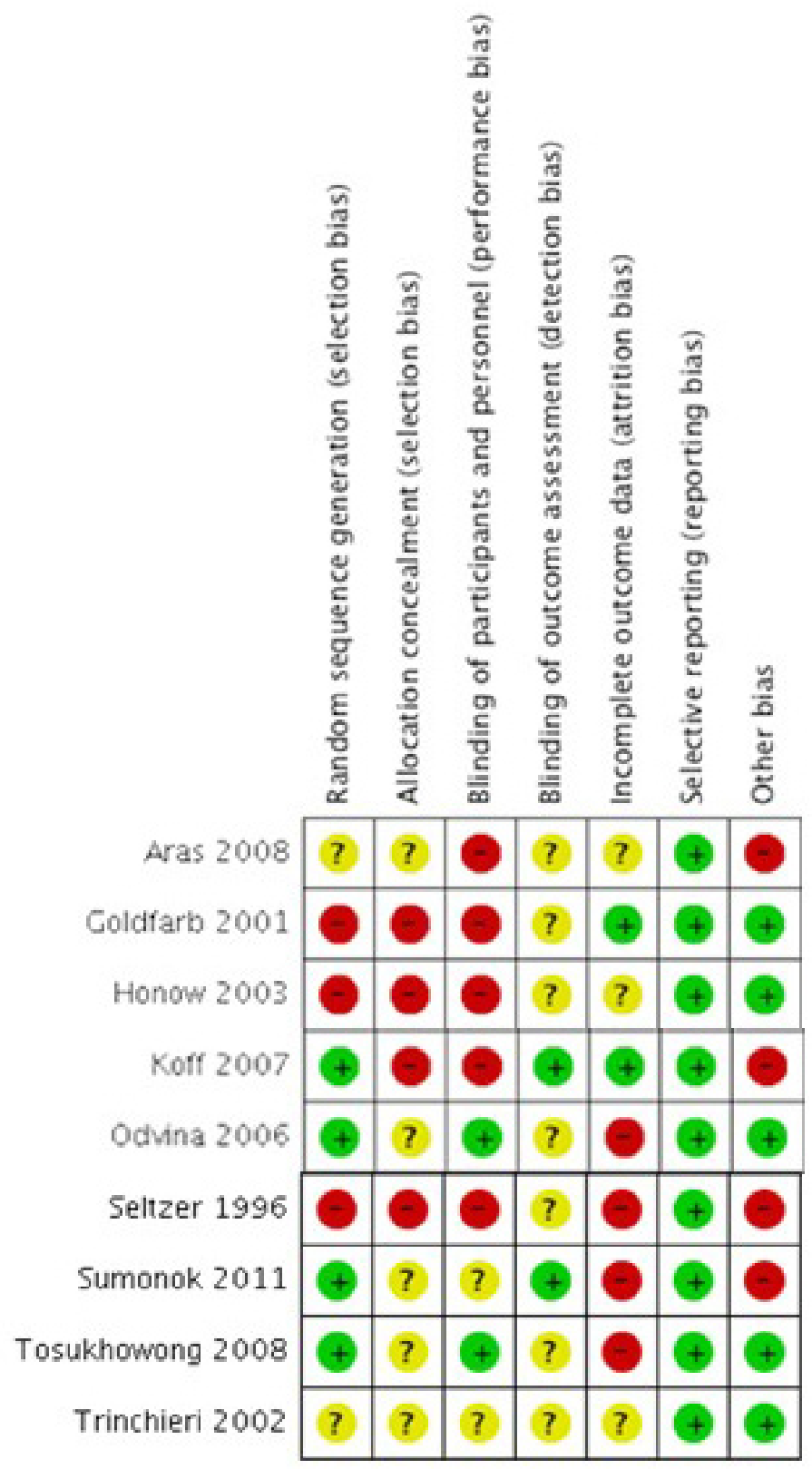

Figure 2. Risk of bias assessment summary.

Dataset 3. Characteristics of studies included for urine volume

http://dx.doi.org/10.5256/f1000research.10976.d153058

Dataset 4. Characteristics of studies included for urinary calcium http://dx.doi.org/10.5256/f1000research.10976.d153059

Dataset 5. Characteristics of studies included for urinary oxalate http://dx.doi.org/10.5256/f1000research.10976.d153060
Dataset 6. Characteristics of studies included for urinary uric acid

http://dx.doi.org/10.5256/f1000research.10976.d153061

\section{Discussion}

This study showed that citrus-based products, such as lemonade, orange juice and grapefruit juice, could increase urinary citrate levels and urine $\mathrm{pH}$. Low citrate excretion, as in type I tubular acidosis, shows an increase in nephrolithiasis incidence ${ }^{27}$. Therefore, existence of citrate in urine is important since it is a well-known preventive factor in calcium stone formation, with an increase in 


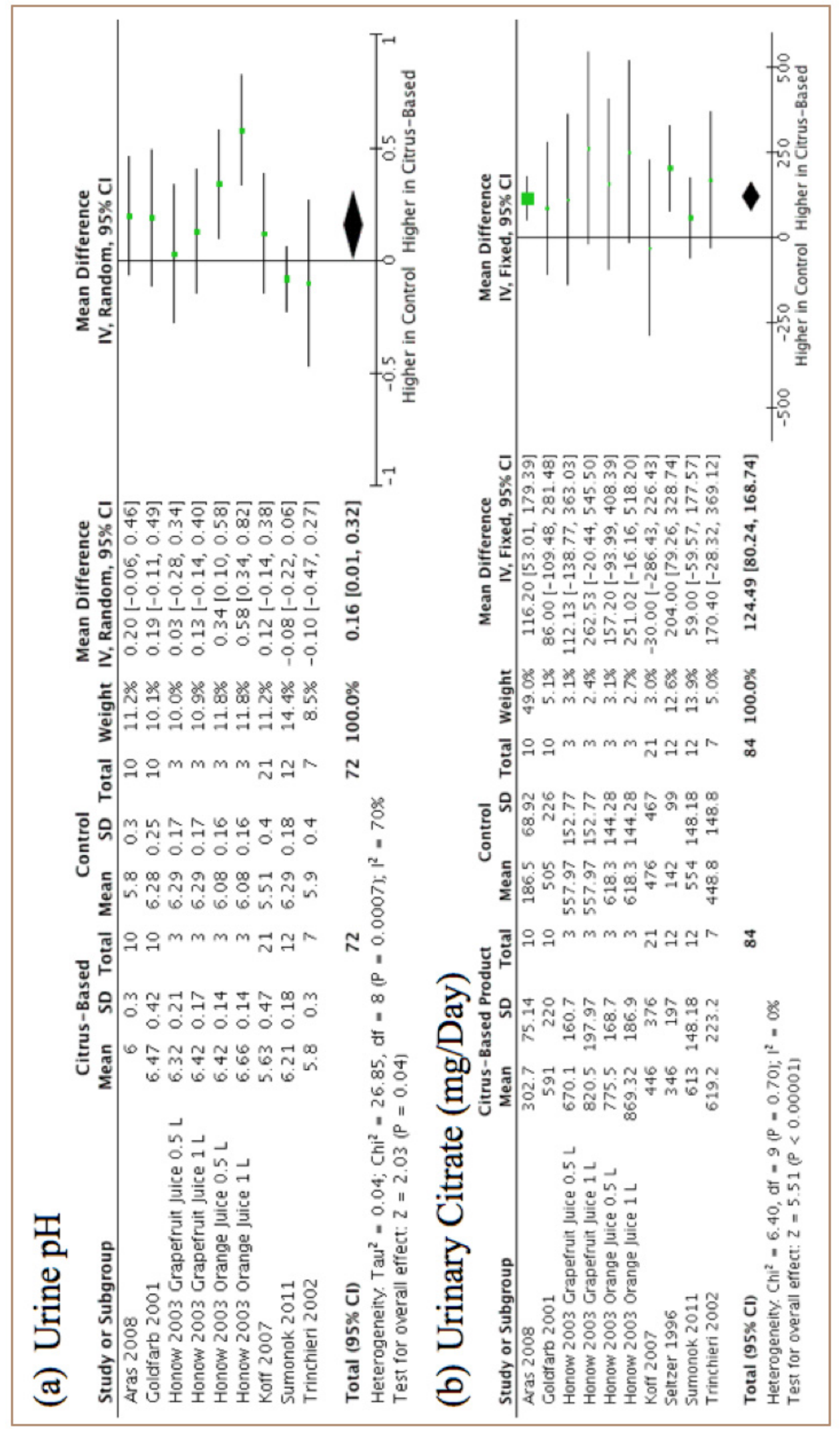




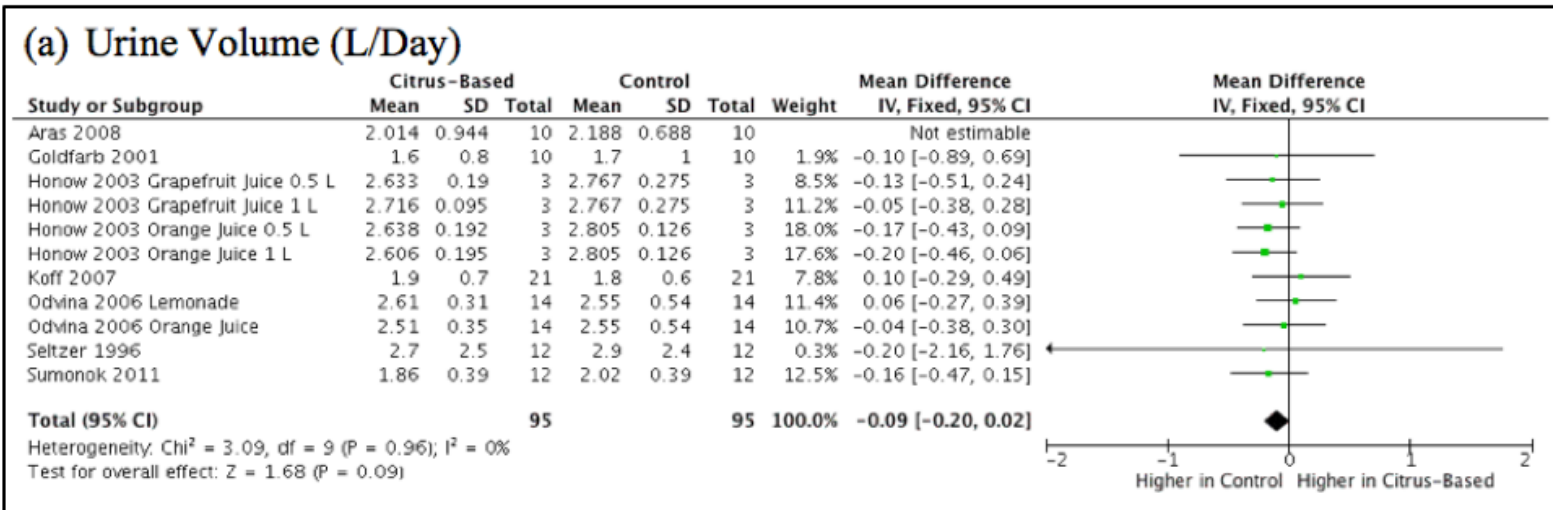

(b) Urinary Calcium (mg/Day)

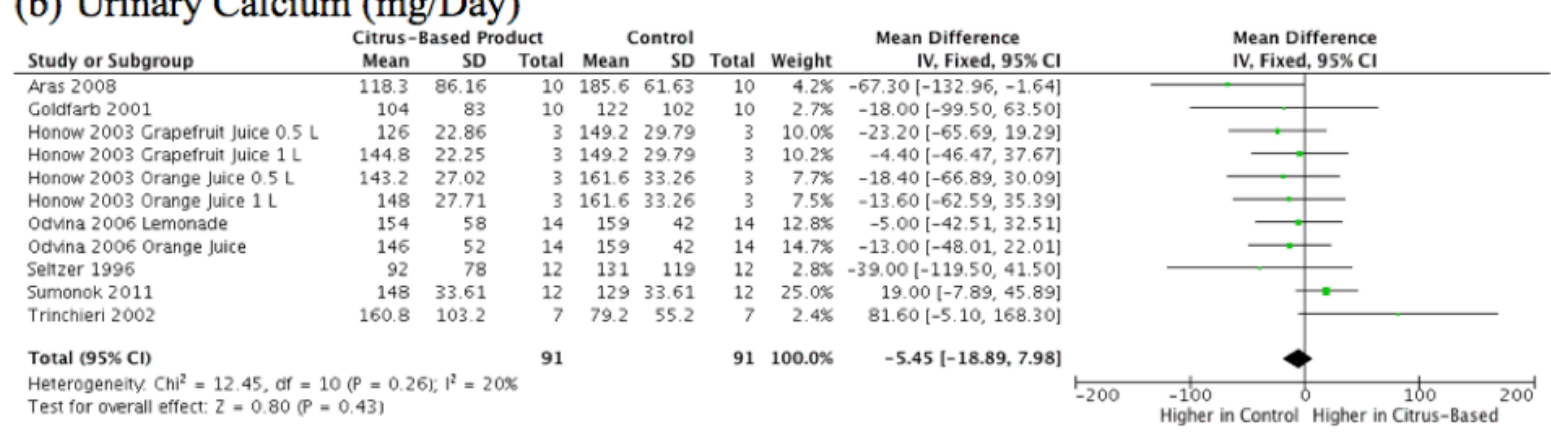

\section{(c) Urinary Oxalate (mg/Day)}

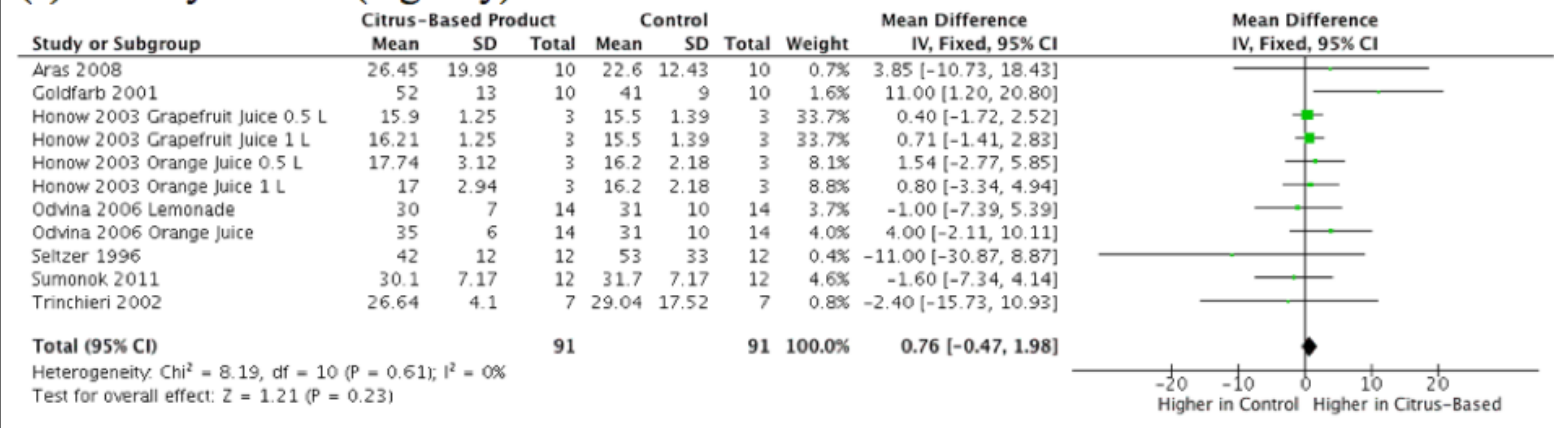

\section{(d) Urinary Uric Acid (mg/Day)}

\begin{tabular}{|c|c|c|c|c|c|c|c|c|c|c|}
\hline \multirow[b]{2}{*}{ Study or Subgroup } & \multicolumn{3}{|c|}{ Citrus-Based Product } & \multicolumn{3}{|c|}{ Control } & \multicolumn{2}{|r|}{ Mean Difference } & \multirow{2}{*}{\multicolumn{2}{|c|}{$\begin{array}{l}\text { Mean Difference } \\
\text { IV, Fixed, } 95 \% \mathrm{Cl}\end{array}$}} \\
\hline & Mean & SD & Total & Mean & SD & Total & Weight & IV, Fixed, $95 \% \mathrm{Cl}$ & & \\
\hline Aras 2008 & 311 & 156.67 & 10 & 427.2 & 194.69 & 10 & $2.8 \%$ & $-116.20[-271.09,38.69]$ & & - \\
\hline Goldfarb 2001 & 544 & 103 & 10 & 562 & 123 & 10 & $6.9 x$ & $-18.00[-117.43,81.43]$ & & \\
\hline Honow 2003 Grapefruit Juice $0.5 \mathrm{~L}$ & 548.08 & 29.12 & 3 & 531.27 & 46.59 & 3 & $17.6 \%$ & $16.81[-45.36,78.98]$ & & \\
\hline Honow 2003 Grapefruit Juice $1 \mathrm{~L}$ & 548.08 & 34.94 & 3 & 531.27 & 46.59 & 3 & $15.7 \%$ & $16.81[-49.09,82.71]$ & & \\
\hline Honow 2003 Orange Juice $0.5 \mathrm{~L}$ & 566.58 & 49.5 & 3 & 532.95 & 32 & 3 & $15.3 \%$ & $33.63[-33.07,100.33]$ & & \\
\hline Honow 2003 Orange Juice $1 \mathrm{~L}$ & 522.86 & 58.23 & 3 & 532.95 & 32 & 3 & 12.18 & $-10.09[-85.28,65.10]$ & & \\
\hline Koff 2007 & 523 & 291 & 21 & 585 & 345 & 21 & $1.8 \%$ & $-62.00[-255.04,131.04]$ & & \\
\hline Odvina 2006 Lemonade & 491 & 81 & 14 & 527 & 123 & 14 & $11.5 \%$ & $-36.00[-113.15,41.15]$ & & - \\
\hline Odvina 2006 Orange Juice & 533 & 116 & 14 & 527 & 123 & 14 & $8.7 \%$ & $6.00[-82.56,94.56]$ & & \\
\hline Seltzer 1996 & 436 & 128 & 12 & 420 & 153 & 12 & $5.4 \%$ & $16.00[-96.87,128.87]$ & & \\
\hline Trinchieri 2002 & 480 & 192 & 7 & 432 & 144 & 7 & 2.28 & $48.00[-129.79,225.79]$ & & \\
\hline \multirow{2}{*}{\multicolumn{3}{|c|}{$\begin{array}{l}\text { Total }(95 \% \mathrm{Cl}) \\
\text { Heterogeneity. Chi } \mathbf{2}^{2}=5.45 \text {, of }=10(P=0.86) ; \mathrm{l}^{2}=0 \% \\
\text { Test for overall effect: } Z=0.16(P=0.87)\end{array}$}} & 100 & & & 100 & $100.0 \%$ & $2.15[-23.96,28.27]$ & & \\
\hline & & & & & & & & & $\begin{array}{l}-2^{1} 00-{ }^{1} 100 \\
\text { Higher in Control }\end{array}$ & $\begin{array}{c}100 \\
\text { Higher in Citrus-Based }\end{array}$ \\
\hline
\end{tabular}

Figure 4. Urine volume, urinary calcium, urinary oxalate, and urinary uric acid levels represented by a forest plot. 


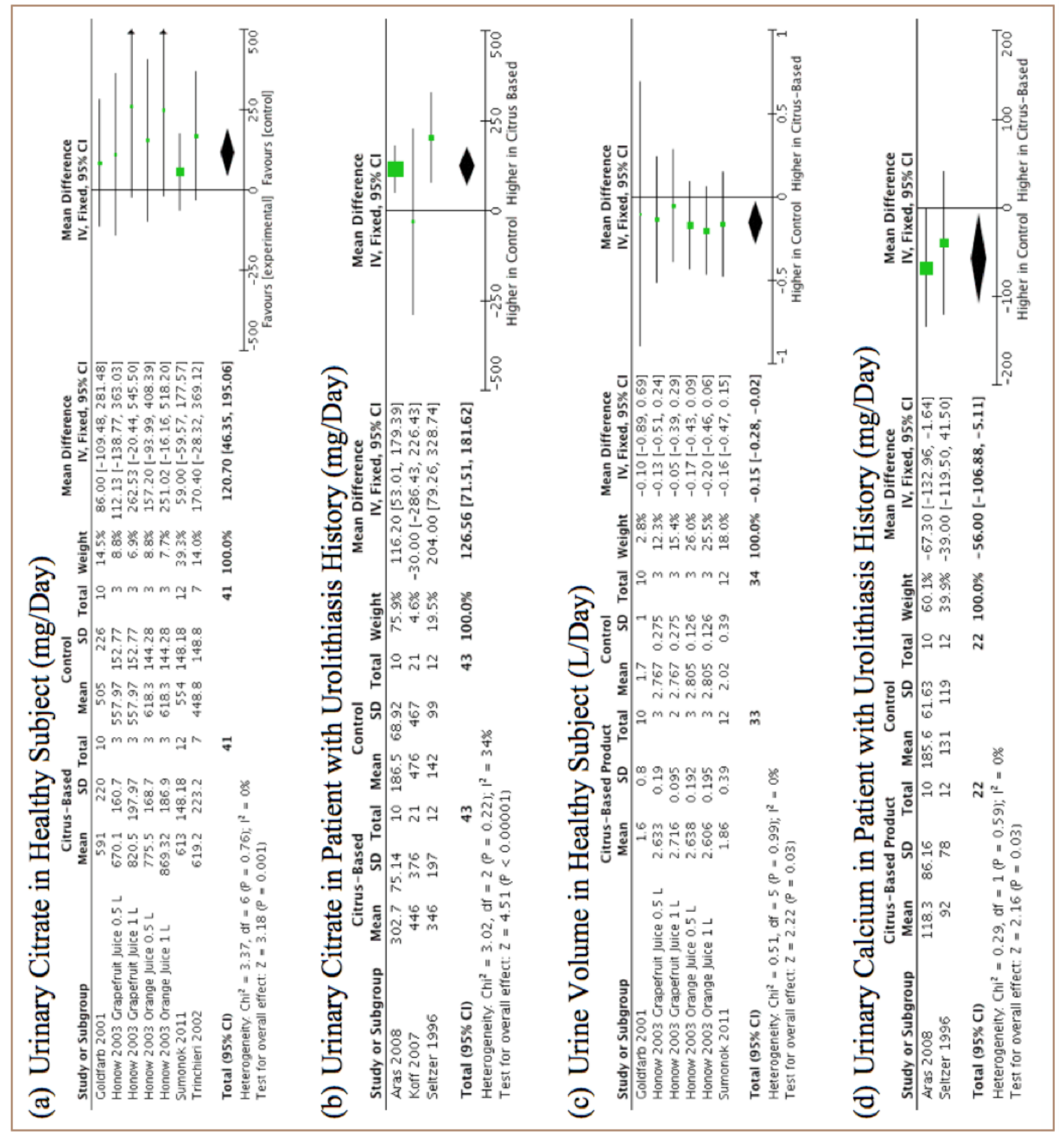


calcium salt solubility and calcium oxalate crystal growth inhibition as its primary mechanism. It also can reduce bone resorption and increase calcium reabsorption in kidneys. Furthermore, citrate fixes the inhibitory properties of Tamm-Horsfall protein ${ }^{28}$. Citrate and Tamm-Horsfall protein are related to inhibition of calcium oxalate agglomeration ${ }^{29}$. An increase in urine $\mathrm{pH}$ is due to metabolism of citrate into bicarbonate ${ }^{13}$. Moreover, an increase in urine $\mathrm{pH}$ could reduce reabsorption of citrate $^{30}$. Thus, it could induce more citrate excretion. A study conducted by Curhan et $a l .{ }^{31}$ found an increased risk of stone formation associated with grapefruit juice consumption; although, the exact mechanism is still unclear. One theory suggests that grapefruit juice contains sugar, which can increase calcium excretion ${ }^{31}$. However, this study proved that citrus-based products could increase urinary citrate level, which could be a protective factor for urinary tract stone formation.

Potassium citrate has been used as urolithiasis stone treatment for more than two decades. Its effectiveness in urolithiasis treatment has been established from several studies ${ }^{32,33}$. From one metaanalysis conducted by Phillip et al., potassium citrate significantly reduced stone size, reduced new stone formation, and increased citrate levels ${ }^{34}$. The stone prevention mechanism of potassium citrate is thought to be due to alkali loading and its citrate-uric effect ${ }^{35}$. In this study, potassium citrate showed a significant increase in urinary citrate and is superior to citrus-based products in elevating urinary citrate. However, the use of potassium citrate has a limitation due to its side effect if used for a long term period, such as epigastric discomfort and frequent large bowel movement, and it requires the consumption of many tablets daily to reach sufficient therapeutic doses, which could dramatically decrease patient compliance ${ }^{36}$. Therefore, citrus-based products could be an alternative therapy with lower cost and better urinary citrate level than control therapy.

This is the first systematic review and meta-analysis that focuses on citrus-based product and its effect towards urine profile compared to standard therapy. However, this study only searched for published article which could lead into publication bias. Moreover, most of the included studies were not conducted using the best method for interventional studies, which is randomized controlled trials. Therefore, from the positive results this study has shown, we encourage other researchers to conduct randomized controlled trials to provide stronger evidence the beneficial effects of citrus-based products on urinary stone disease.

\section{Conclusions}

Citrus-based products increase urinary citrate and urine $\mathrm{pH}$ significantly compared to control treatments. Compared to standard potassium citrate therapy, there was a smaller increase in urine $\mathrm{pH}$ and urine citrate using citrus-based products. However, due to potassium citrate side effects and patient's poor compliance, citrus-based products could be alternative therapy in preventing stone formation. These study's results should encourage further research to explore citrus-based product as a urolithiasis treatment.

\section{Data availability}

Dataset 1: Characteristics of studies included for urine $\mathrm{pH}$. doi, 10.5256/f1000research.10976.d153056 ${ }^{37}$

Dataset 2: Characteristics of studies included for urinary citrate. doi, 10.5256/f1000research.10976.d153057 38

Dataset 3: Characteristics of studies included for urine volume. doi, 10.5256/f1000research.10976.d153058 $8^{39}$

Dataset 4: Characteristics of studies included for urinary calcium. doi, 10.5256/f1000research.10976.d153059 ${ }^{40}$

Dataset 5: Characteristics of studies included for urinary oxalate. doi, 10.5256/f1000research.10976.d153060

Dataset 6: Characteristics of studies included for urinary uric acid. doi, 10.5256/f1000research.10976.d153061 ${ }^{42}$

\section{Author contributions}

PB and NR developed the concept of this study. IW designed the research methodology. FR did the literature searching. FR and PB did the selection of studies. FR prepared the draft of manuscript. All author contributed in the revision of the draft manuscript and have agreed to the final content.

\section{Competing interests}

No competing interests were disclosed.

\section{Grant information}

This study received grants from Directorate of Research and Community Service (DRPM), Universitas Indonesia in 2013 (2739/ H.R12/HKT.05.00/2013).

The funders had no role in study design, data collection and analysis, decision to publish, or preparation of the manuscript.

\section{Supplementary material}

Supplementary Table 1. Newcastle-Ottawa scale for retrospective study's risk of bias assessment.

Click here to access the data.

Supplementary Table 2: PRISMA checklist.

Click here to access the data.

Supplementary Figure 1. Urine pH, urinary calcium, urinary oxalate, and urinary uric acid in healthy subject population. Click here to access the data.

Supplementary Figure 2. Urine volume, urine $\mathrm{pH}$, urinary oxalate, and urinary uric acid in population with a history of urolithiasis. 
1. Eknoyan G: History of urolithiasis. Clinical Reviews in Bone and Mineral Metabolism. 2004; 2(3): 177-85. Publisher Full Text

2. Trinchieri A: Epidemiology of urolithiasis. Arch Ital Urol Androl. 1996; 68(4): 203-49. PubMed Abstract

3. Türk C, Knoll T, Petrik A, et al.: Pocket Guidelines on urolithiasis. Eur Urol. 2014; 40(4): 362-71.

4. Fukuhara $\mathrm{H}$, Ichiyanagi $\mathrm{O}$, Kakizaki $\mathrm{H}$, et al.: Clinical relevance of seasonal changes in the prevalence of ureterolithiasis in the diagnosis of renal colic. Urolithiasis. 2016; 44(6): 529-537.

PubMed Abstract | Publisher Full Text | Free Full Text

5. Muslumanoglu AY, Binbay M, Yuruk E, et al:: Updated epidemiologic study of urolithiasis in Turkey. I: Changing characteristics of urolithiasis. Urol Res. 2011; 39(4): 309-14.

PubMed Abstract | Publisher Full Text

6. Edvardsson VO, Indridason OS, Haraldsson G, et al:: Temporal trends in the incidence of kidney stone disease. Kidney Int. 2013; 83(1): 146-52. PubMed Abstract | Publisher Full Text

7. Scales CD Jr, Smith AC, Hanley JM, et al:: Prevalence of kidney stones in the United States. Eur Urol. 2012; 62(1): 160-5.

PubMed Abstract | Publisher Full Text | Free Full Text

8. Indonesia IAU: Tatalaksana Batu Saluran Kemih 2007.

9. Singh P, Enders FT, Vaughan LE, et al:: Stone Composition Among First-Time Symptomatic Kidney Stone Formers in the Community. Mayo Clin Proc. 2015; 90(10): 1356-65.

PubMed Abstract | Publisher Full Text | Free Full Text

10. Moses R, Pais VM Jr, Ursiny M, et al.: Changes in stone composition over two decades: evaluation of over $\mathbf{1 0 , 0 0 0}$ stone analyses. Urolithiasis. 2015; $\mathbf{4 3}(2)$ : 135-9.

PubMed Abstract | Publisher Full Text

11. Park S, Pearle MS: Pathophysiology and management of calcium stones. Uro Clin North Am. 2007; 34(3): 323-34. PubMed Abstract | Publisher Full Text

12. Maalouf N: Approach to the adult kidney stone former. Clin Rev Bone Min Metab. 2012; 10(1): 38-49.

PubMed Abstract | Publisher Full Text | Free Full Text

13. Tracy CR, Pearle MS: Update on the medical management of stone disease. Curr Opin Urol. 2009; 19(2): 200-4. PubMed Abstract | Publisher Full Tex

14. Siener R: Can the manipulation of urinary $\mathrm{pH}$ by beverages assist with the prevention of stone recurrence? Urolithiasis. 2016; 44(1): 51-6.

PubMed Abstract | Publisher Full Text

15. Higgins JP, Altman DG, Gøtzsche PC, et al:: The Cochrane Collaboration's tool for assessing risk of bias in randomised trials. BMJ. 2011; 343: d5928. PubMed Abstract | Publisher Full Text | Free Full Text

16. Wells GA, Shea B, O'Connell D, et al.: The Newcastle-Ottawa Scale (NOS) for assessing the quality of nonrandomised studies in meta-analyses. Ottawa, ON: Ottawa Hospital Research Institute; [Accessed September 1, 2016]. 2011. Reference Source

17. Penniston KL, Steele TH, Nakada SY: Lemonade therapy increases urinary citrate and urine volumes in patients with recurrent calcium oxalate ston formation. Urology. 2007; 70(5): 856-60 PubMed Abstract | Publisher Full Tex

18. Sumorok NT, Asplin JR, Eisner BH, et al:: Effect of diet orange soda on urinary lithogenicity. Urol Res. 2012; 40(3): 237-41. PubMed Abstract | Publisher Full Text

19. Tosukhowong $\mathrm{P}$, Yachantha $\mathrm{C}$, Sasivongsbhakdi $\mathrm{T}$, et al.: Citraturic, alkalinizing and antioxidative effects of limeade-based regimen in nephrolithiasis patients. Urol Res. 2008; 36(3-4): 149-55. PubMed Abstract | Publisher Full Tex

20. Aras B, Kalfazade N, Tuğcu V, et al:: Can lemon juice be an alternative to potassium citrate in the treatment of urinary calcium stones in patients with hypocitraturia? A prospective randomized study. Urol Res. 2008; 36(6): 313-7. PubMed Abstract | Publisher Full Text

21. Goldfarb DS, Asplin JR: Effect of grapefruit juice on urinary lithogenicity. J Urol. 2001; 166(1): 263-7.

PubMed Abstract | Publisher Full Tex

22. Hönow R, Laube N, Schneider A, et al.: Influence of grapefruit-, orange- and apple-juice consumption on urinary variables and risk of crystallization. Br J Nutr. 2003; 90(2): 295-300.

PubMed Abstract | Publisher Full Text

23. Koff SG, Paquette EL, Cullen J, et al:: Comparison between lemonade and potassium citrate and impact on urine $\mathrm{pH}$ and 24-hour urine parameters in patients with kidney stone formation. Urology. 2007; 69(6): 1013-6. PubMed Abstract | Publisher Full Text

24. Odvina CV: Comparative value of orange juice versus lemonade in reducing stone-forming risk. Clin J Am Soc Nephrol. 2006; 1(6): 1269-74.

PubMed Abstract | Publisher Full Text

25. Seltzer MA, Low RK, McDonald M, et al.: Dietary manipulation with lemonade to treat hypocitraturic calcium nephrolithiasis. J Urol. 1996; 156(3): 907-9. PubMed Abstract | Publisher Full Text

26. Trinchieri A, Lizzano R, Bernardini $P$, et al:: Effect of acute load of grapefruit juice on urinary excretion of citrate and urinary risk factors for renal stone formation. Dig Liver Dis. 2002; 34(Suppl 2): S160-3.

PubMed Abstract | Publisher Full Text

27. Khanniazi MK, Khanam A, Naqvi SA, et al:: Study of potassium citrate treatment of crystalluric nephrolithiasis. Biomed Pharmacother. 1993; 47(1): 25-8. PubMed Abstract | Publisher Full Text

28. Fuselier HA, Ward DM, Lindberg JS, et al.: Urinary Tamm-Horsfall protein increased after potassium citrate therapy in calcium stone formers. Urology. 1995; 45(6): 942-6.

PublMed Abstract | Publisher Full Text

29. Laube N, Jansen B, Hesse A: Citric acid or citrates in urine: which should we focus on in the prevention of calcium oxalate crystals and stones? Urol Res. 2002; 30(5): 336-41.

PubMed Abstract | Publisher Full Text

30. Heilberg IP, Goldfarb DS: Optimum nutrition for kidney stone disease. Adv Chronic Kidney Dis. 2013; 20(2): 165-74. PubMed Abstract | Publisher Full Text

31. Curhan GC, Willett WC, Rimm EB, et al:: Prospective study of beverage use and the risk of kidney stones. Am J Epidemiol 1996; 143(3): 240-7. PubMed Abstract | Publisher Full Text

32. Robinson MR, Leitao VA, Haleblian GE, et al:: Impact of long-term potassium citrate therapy on urinary profiles and recurrent stone formation. J Urol. 2009; 181(3): 1145-50.

PubMed Abstract | Publisher Full Text

33. Allie-Hamdulay S, Rodgers AL: Prophylactic and therapeutic properties of a sodium citrate preparation in the management of calcium oxalate urolithiasis: randomized, placebo-controlled trial. Urol Res. 2005; 33(2): 116-24. PubMed Abstract | Publisher Full Text

34. Phillips R, Hanchanale VS, Myatt A, et al.: Citrate salts for preventing and treating calcium containing kidney stones in adults. Cochrane Database Syst Rev. 2015; 10(10): CD010057.

PubMed Abstract | Publisher Full Text

35. Ettinger B, Pak CY, Citron JT, et al:: Potassium-magnesium citrate is an effective prophylaxis against recurrent calcium oxalate nephrolithiasis. J Urol. 1997; 158(6): 2069-73.

PubMed Abstract | Publisher Full Text

36. Lee YH, Huang WC, Tsai JY, et al.: The efficacy of potassium citrate based medical prophylaxis for preventing upper urinary tract calculi: a midterm followup study. J Urol. 1999; 161(5): 1453-7.

PubMed Abstract | Publisher Full Text

37. Rahman F, Birowo P, Widyahening IS, et al:: Dataset $\mathbf{1}$ in: Effect of citrus-based products on urine profile: A systematic review and meta-analysis. F1000Research. 2017 Data Source

38. Rahman F, Birowo P, Widyahening IS, et al.: Dataset 2 in: Effect of citrus-based products on urine profile: A systematic review and meta-analysis. F1000Research. 2017. Data Source

39. Rahman F, Birowo P, Widyahening IS, et al:: Dataset 3 in: Effect of citrus-based products on urine profile: A systematic review and meta-analysis. F1000Research. 2017. Data Source

40. Rahman F, Birowo P, Widyahening IS, et al:: Dataset 4 in: Effect of citrus-based products on urine profile: A systematic review and meta-analysis. F1000Research. 2017 Data Source

41. Rahman F, Birowo P, Widyahening IS, et al:: Dataset $\mathbf{5}$ in: Effect of citrus-based products on urine profile: A systematic review and meta-analysis. F1000Research. 2017. Data Source

42. Rahman F, Birowo P, Widyahening IS, et al: Dataset 6 in: Effect of citrus-based products on urine profile: A systematic review and meta-analysis. F1000Research. 2017 Data Source 


\section{Open Peer Review}

\section{Current Peer Review Status:}

\section{Version 1}

Reviewer Report 08 May 2017

https://doi.org/10.5256/f1000research.11834.r22426

(C) 2017 Somani B. This is an open access peer review report distributed under the terms of the Creative Commons Attribution License, which permits unrestricted use, distribution, and reproduction in any medium, provided the original work is properly cited.

\section{Bhaskar K Somani}

University Hospitals Southampton NHS Trust, Urology, Southampton, SO16 6YD., UK

The authors present a comprehensive systematic review and meta-analysis of the effect of citrusbased products on urine profile. The paper is supplemented by the PRISMA flow chart and forest plot charts to present their results.

Although their search strategy is good, they should have used other terms such as 'kidney stones', 'stones', 'ureteric stones' and 'calculi' too. They have only used the term 'Urolithiasis' which could potentially miss on other relevant studies.

As a limitation of any systematic review the authors are correct in acknowledging that their is likely to be a publication bias. Similarly, the long term effect of the use of citrate-based products in not know from this study and whether their results translate into a reduction in stone recurrences remain unknown.

A recent cochrane review on the use of citrate salts on prevention and treatment of calcium containing kidney stones in adults showed a reduction in new stone formation and stone recurrences in these patients ${ }^{1}$.

Overall the paper reads well and is a nice summary on the use of citrate based products on urine profile.

\section{References}

1. Phillips R, Hanchanale VS, Myatt A, Somani B, et al.: Citrate salts for preventing and treating calcium containing kidney stones in adults.Cochrane Database Syst Rev. 2015. CD010057 PubMed Abstract | Publisher Full Text

\section{Are the rationale for, and objectives of, the Systematic Review clearly stated?} Yes 
Are sufficient details of the methods and analysis provided to allow replication by others? Yes

Is the statistical analysis and its interpretation appropriate?

Yes

Are the conclusions drawn adequately supported by the results presented in the review? Yes

Competing Interests: No competing interests were disclosed.

I confirm that I have read this submission and believe that I have an appropriate level of expertise to confirm that it is of an acceptable scientific standard.

Reviewer Report 02 May 2017

https://doi.org/10.5256/f1000research.11834.r21950

(C) 2017 Goldfarb D. This is an open access peer review report distributed under the terms of the Creative Commons Attribution License, which permits unrestricted use, distribution, and reproduction in any medium, provided the original work is properly cited.

\section{David S Goldfarb}

NYU Langone Medical Center and NYU School of Medicine, New York, NY, USA

1. The authors are correct in stating that no previous meta-analysis of the effects of citrus fruits has been performed. The results are not surprising as stone clinicians consider citrus supplementation (or potassium citrate) of important utility. However, the meta-analysis is reasonable to perform as the intervention is commonly administered.

2.The studies are similar enough to consider a meta-analysis worth doing. One study used diet orange soda which is not citrus juice (I am the senior author of that study). There is otherwise an appropriate selection of studies, based on availability of the requisite data which the authors explain in detail.

3. The limitations of the data include the relatively small sample size, so that the meta-analysis is also underpowered but shows the expected increase in urine citrate and the increase in urine $\mathrm{pH}$ only in stone formers and not in non-stone forming controls. No studies actually assess stone formation as an outcome, addressing only urinary chemistry.

4. The conclusions appear reasonable, and are well-stated, if not surprising.

5. Table 1 could be improved by including the dose of juice for all the interventions.

6. I did not find a legend for figure 2 about bias assessment. The figure is hazy, not of perfect resolution. There is no interpretation of the bias assessment in the manuscript. It is worth noting that it is probably not possible to blind participants to citrus juice vs water. The other criteria, such as blinding to sequence allocation may also not be critical to a study of urine chemistry and not of kidney stone outcomes.

7. Regarding Curhan's finding that grapefruit juice was associated with higher risk for stones, mentioned in the discussion, that finding was not confirmed in a later study ${ }^{1}$. 
8. In the introduction, the authors state "whereas citrate could prevent stone formation by ionizing urinary calcium": this is not quite correct. Citrate binds to ionic calcium and prevents it from binding to oxalate or phosphate.

\section{References}

1. Ferraro PM, Taylor EN, Gambaro G, Curhan GC: Soda and other beverages and the risk of kidney stones.Clin J Am Soc Nephrol. 2013; 8 (8): 1389-95 PubMed Abstract | Publisher Full Text

Are the rationale for, and objectives of, the Systematic Review clearly stated?

Yes

Are sufficient details of the methods and analysis provided to allow replication by others? Yes

Is the statistical analysis and its interpretation appropriate?

Yes

Are the conclusions drawn adequately supported by the results presented in the review? Yes

Competing Interests: Owner of the Ravine Group, see http://www.filamentbiosolutions.com/Pressreleases/filament-announces-licensing-agreement.html. Disclosure: I am an author of 2 of the papers included in the study: Goldfarb, and Sumorok.

Reviewer Expertise: Nephrolithiasis, kidney stones, calculi, renal, chronic kidney disease, end stage renal disease, electrolytes and acid-base balance, gout

I confirm that I have read this submission and believe that I have an appropriate level of expertise to confirm that it is of an acceptable scientific standard. 
The benefits of publishing with F1000Research:

- Your article is published within days, with no editorial bias

- You can publish traditional articles, null/negative results, case reports, data notes and more

- The peer review process is transparent and collaborative

- Your article is indexed in PubMed after passing peer review

- Dedicated customer support at every stage

For pre-submission enquiries, contact research@f1000.com 